\title{
Chronic myalgia centrally mediated
}

\author{
Mialgia crônica mediada centralmente
}

Felipe Lara FRANCISCHETTI ${ }^{1}$

Antônio Márcio Lima FERRAZ JÚNIOR ${ }^{1}$

Luciano Ambrosio FERREIRA ${ }^{1}$

Antonio Carlos Pires CARVALHO²

Josemar Parreira GUIMARÃES'

\begin{abstract}
The clinical case report of a 50-year-old patient who presented to the Diagnostic and Guidance Service for Patients with Temporomandibular Disorders, at the School of Dentistry, Federal University of Juiz de Fora, with complaint of pain in the facial muscles in a continuous, throbbing manner that was paroxysmal at times, with severe intensity and of a chronic nature. After semiological interdisciplinary examination (dental, speech and physical therapy), the diagnosis suggestive of temporomandibular disorder was reached, characterized by centrally mediated chronic myalgia, associated with articular structures, parafunctional habits, malocclusion and emotional factors. Supportive dental treatment consisted of guidance throughout treatment and use of occlusal splints. After a three-and-a-half-month period of interdisciplinary therapy the patient was discharged with an $80 \%$ improvement in pain and increase in mouth opening amplitude. Episodes of pain were related only to moments of stress. The patient was instructed about the need for orthodontic treatment and psycho therapy.
\end{abstract}

Indexing terms: Chronic pain. Interdisciplinary research. Temporomandibular joint disorders.

\section{RESUMO}

O caso clínico reporta uma paciente de 50 anos que se apresentou ao Serviço de Diagnóstico e Orientação a Pacientes com Desordens Temporomandibulares da Faculdade de Odontologia da Universidade Federal de Juiz de Fora com queixa de dores nos músculos da face de modo contínuo, do tipo latejante, às vezes paroxístico, de intensidade severa e caráter crônico. Após exame semiológico interdisciplinar (odontológico, fonoaudiológico e fisioterapêutico), chegou-se ao diagnóstico sugestivo de desordem temporomandibular caracterizado por mialgia crônica mediada centralmente, associada às alterações articulares, hábitos parafuncionais, má oclusão e fatores emocionais. O tratamento odontológico de suporte constituiu-se de orientações ao longo do tratamento e uso da placa neuromiorrelaxante. Após um período de 3 meses e meio de terapia interdisciplinar a paciente recebeu alta com melhora de $80 \%$ das dores e aumento da amplitude de abertura bucal. Relacionou episódios de dor somente em momentos de estresse. Foi orientada sobre a necessidade de tratamento ortodôntico e psicoterapia.

Termos de indexação: Dor crônica. Pesquisa interdisciplinar. Transtornos da articulação temporomandibular.

\section{INTRODUCTION}

Temporomandibular disorder is characterized by a variety of signs and symptoms, frequently exacerbated by mandibular movements, which may also be present at rest ${ }^{1-4}$. The pains may be classified according to the stage at which they are found: acute or chronic ${ }^{5}$.

Centrally mediated chronic myalgia is a chronic, continuous muscle disorder, originating in the central nervous system, which generates symptoms at the periphery of muscle tissues ${ }^{4}$. Pain at rest is the key factor of the clinical characteristics of this disorder and probably occurs due to the sensitization of the muscle nociceptors by algogenic substances released in the neurogenic inflammatory process ${ }^{4}$.

The main therapeutic modalities for this pathological process, described by Okeson ${ }^{4}$ are: reversible occlusal therapy, restriction of movements of the mandible, adoption of dietary habits, with inclusion of pastier foods and interdisciplinary follow-up.

\footnotetext{
${ }^{1}$ Universidade Federal de Juiz de Fora, Faculdade de Odontologia, Serviço de Diagnóstico e Orientação a Pacientes com Desordens Temporomandibulares (SERVIÇO ATM). Rua José Lourenço Kelmer, Campus Universitário, São Pedro, 36036-900, Juiz de Fora, MG, Brasil. Correspondência para / Correspondence to: FL FRANCISCHETTI. E-mail: <feliplf@gmail.com>.

${ }^{2}$ Universidade Federal do Rio de Janeiro, Faculdade de Medicina, Departamento de Radiologia. Rio de Janeiro, RJ, Brasil.
} 


\section{CLINICAL CASE}

The patient VLS (Figure 1) a 50-year-old white woman, presented to the Diagnostic and Guidance Service for Patients with Temporomandibular Disorders (ATMService) of the School of Dentistry, Federal University of Juiz de Fora in 2008, complaining of pain in the muscles of the face, bilaterally, both in movement and when at rest. During anamnesis the patient complained of continuous pain, of the throbbing, sometimes paroxistic type, of severe intensity and of a chronic nature. She also reported that the pains had intensified during the last six months. Parafunctional habits, such as jaw clenching and unilateral chewing, buzzing noises (in the ears)?/ and headaches were reported. Her medical history related arterial hypertension, hypercholesterolemia, hypothyroidism, diminished hearing, arthrosis (in the elbow region) and a high degree of stress and anxiety.

On dental and occlusal exam, overjet of 3 millímeters $(\mathrm{mm})$ and overbite of $7 \mathrm{~mm}$ were found, characterizing deep bite, flat curve of Spee and Angle's Class II (molar relationship) (Figure 2). A discrepancy of $3 \mathrm{~mm}$ between centric relation and centric occlusion was observed.
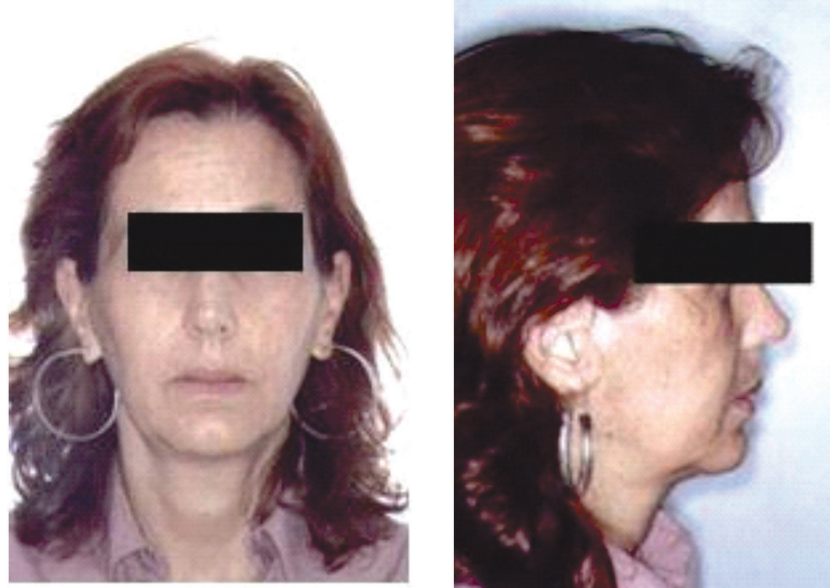

Figure 1. Extraoral photographs of the patient (Front view and profile).

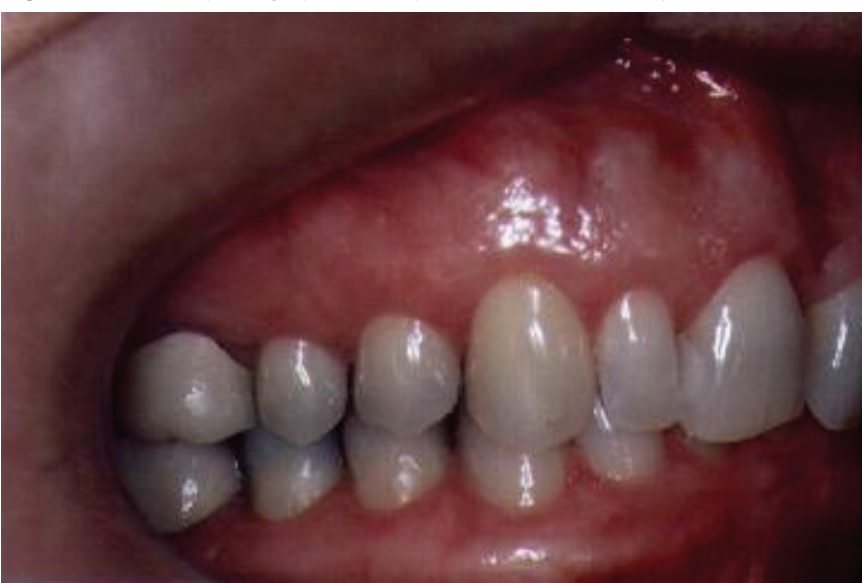

Figure 2. Intraoral photograph (right side)
On examination of the temporomandibular joint, she related pain on lateral palpation with the fingertips, and bilateral intra-auditory canal pain of light intensity. Clicking sound was found during mouth opening, only on the right side. Maximum mouth opening without discomfort was $28 \mathrm{~mm}$, and with discomfort - $35 \mathrm{~mm}$, as there was mandibular deviation to the right. Palpation with fingertips revealed pain of severe intensity bilaterally on the masseter, medial and lateral pterygoid muscles, superior portion of the trapezius muscle, and of light intensity bilaterally on the temporal and sternocleidomastoid muscles.

Radiographic exam (planigraphy of the TMJ) suggested anterior and posterior flattening of the condyle bilaterally, shown in the images recording the position of the closed mouth, bilaterally (Figure 3).

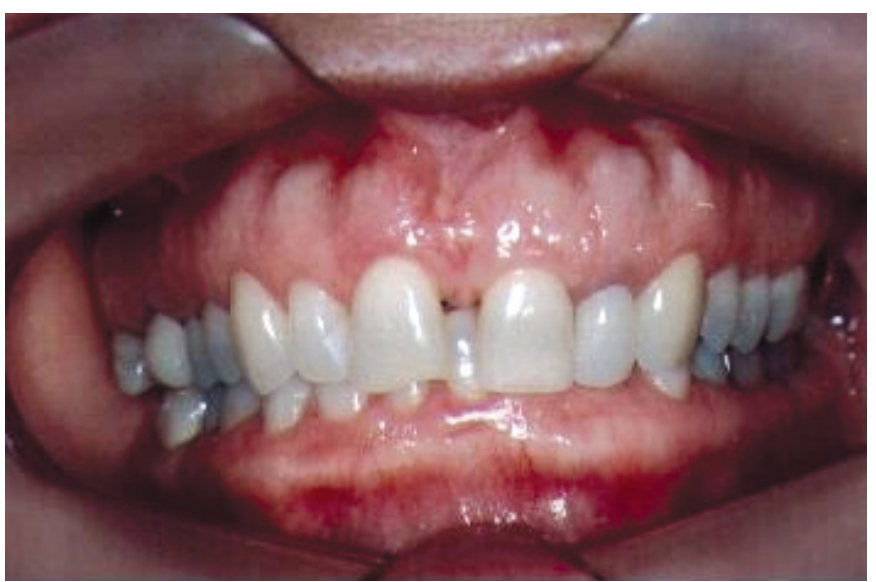

Figure 3. Intraoral photograph (front view).

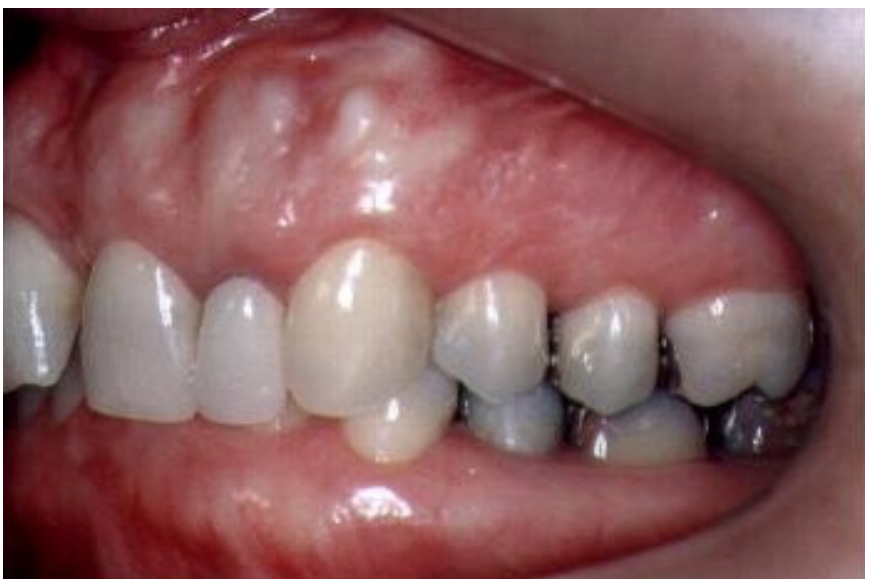

Figure 4. Intraoral photograph (left side).

In view of the data obtained in the clinical exam it was possible to reach the diagnosis suggestive of temporomandibular disorder, presenting centrally mediated chronic myaliga, anterior disc displacement with reduction on the right side, with presence of parafunctional habits (clenching and unilateral chewing), malocclusion and emotional stress as additional factors. 

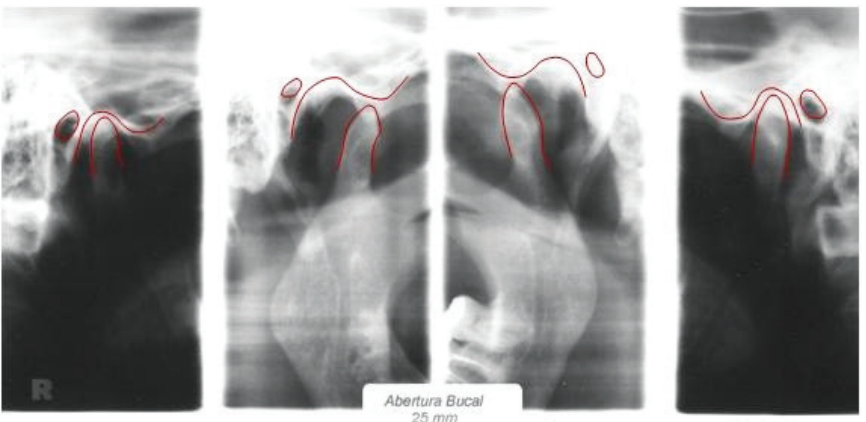

Figure 5. TMJ Planigraphy.

The patient was examined by the speech and physical therapy sectors, which recommended a pasty diet and physical therapy exercises. For dental therapy an occlusal splint was used, which was fabricated in order to simulate a physiologically ideal occlusion.

The patient was instructed to use this occlusal splint for $24 \mathrm{~h} /$ day initially, and remove it when eating and performing oral hygiene. She reported full improvement of the muscular pains after one week of treatment, and was instructed to continue using the occlusal splint for $24 \mathrm{~h} /$ day. After 6 weeks of treatment the patient reported significant improvement of the muscular pains, and headache of only light intensity. She was instructed to reduce the use of the occlusal splint to $16 \mathrm{~h} /$ day. After nine months the patient reported an $80 \%$ improvement in general pain, presenting localized sensitivity in the masseter muscles bilaterally, with the use of the occlusal splint having been reduced to $12 \mathrm{~h} /$ day. In the tenth week, the pain condition remained stable, and only nocturnal use of the occlusal splint ( $8 \mathrm{~h} /$ day) was indicated. In the thirteenth week of using the occlusal splint, there was continued improvement in the general pain condition, with the pains only being manifested in situations of stress; and mouth opening was $42 \mathrm{~mm}$. A term of discharge was signed, and as complementary therapy, orthodontic and psycho therapy evaluations were suggested.

The clinical case in question was conducted in compliance with the ethical principles contained in the Declaration of Helsinki and Chapter IV of the National Health Council Resolution 196/96; also in conformity with the legislation in force in Brazil, and approval of the Research Ethics Committee of the Federal University of Juiz de Fora in Process No.826.170.2009.

\section{DISCUSSION}

Due to the constant pains over the previous six months, associated with reduced amplitude of mandibular movement, pain at res, with exacerbation during movement and intense pain on palpation, the diagnosis of centrally mediated chronic myalgia was reached ${ }^{3-4,6-7}$.

The patient in question presented various contributing factors for the onset and permanence of centrally mediated chronic myalgia, which were detected by the clinical exam. Although the patho-physiological mechanisms of muscle pain at rest have not been completely elucidated, it is believed to arise from muscle hyperactivity and hyperexcitability of the central nervous system, which are involved in a cycle of feedback ${ }^{4,7-9}$.

Malocclusion is considered an etiologic and aggravating factor of temporomandibular disorder, and may be one of the causes of muscle hyperactivity ${ }^{4}$, together with parafunctional habits (such as clenching and unilateral chewing), which general occlusal, muscle and joint overloads. The discrepancy of $3 \mathrm{~mm}$ may be a contributory factor to the patient's symptomatology because, according to Okeson ${ }^{4}$, a slide of up to $2 \mathrm{~mm}$ in centric relation to centric occlusion is common, but is not considered functionally ideal. In the present case even the functional movements of the mandible, particularly of mastication and speed, aggravated the pains.

Diverse factors are related to limitation of mouth opening. In this clinical case it could be related to a consequence of muscle pain of a chronic and intense nature associated with articular alterations. The limitation of this movement may be considered a sign of temporomandibular disorder ${ }^{11}$. This limitation is explained as a mechanism of protection of the tissues involved ${ }^{3,12}$, and may affect both mastication and speech. ${ }^{11,15}$

Radiographic imaging showed an anterior bilateral flattening of the condyle. This sign associated with the medical history of arthrosis in the elbow must alert the dental surgeon to possible later alterations in the bony/cartilaginous components of the temporomandibular joint ${ }^{16-17}$.

Systemic diseases such as arterial hypertension may be related to a higher level of pain in patients with temporomandibular disorder, mainly when associated with situations of stress ${ }^{2}$. The high levels of stress and anxiety of these patients may be one of the causes of and/or contributory to the aggravation of the pathological condition?

\section{CONCLUSION}

Temporomandibular disorder is a pathological condition associated with interrelated factors. Therefore its treatment requires an interdisciplinary approach. The occlusal splint was efficient for the purpose of simulating a satisfactory 
occlusion that would help to diminish the deleterious effects of the parafunctional habits and malocclusion. The guidance as regards a soft diet, together with the physical therapy exercises were successful in diminishing the masticatory overload, obtaining muscle relaxation, and consequently, in reducing the pain. The presence of various systemic diseases in the patient, associated with high levels of anxiety and stress, may justify the incomplete remission of the symptomatology.

\section{Collaborators}

FL FRANCISCHETTI was responsible for clinical attendance of the patient, review of the literature and writing the article. AML FERRAZ JÚNIOR, LA Ferreira, ACP Carvalho and JP Guimarães participated in the review of the literature and writing the article.

\section{REFERENCES}

1. Felício CM, Melchior MO, Silva MAMR, Coleghini RMS. Desempenho mastigatório em adultos relacionado com a desordem temporomandibular e com a oclusão. Pró-Fono R Atual Cient. 2007;19(2):151-8. doi: 10.1590/S0104-56872007000200003.

2. Haesbaert BM, Ferreira GC, Barp G, Grossi ML. Associação entre pressão sangüínea com sinais e sintomas de dor orofacial e disfunção temporomandibular. Rev Odonto Ciência. 2005;20(47):45-9.

3. Lobbezoo F, van Selms MKA, Naeije M. Masticatory muscle pain and disordered jaw motor behaviour: Literature review over the past decade. Arch Oral Biol. 2006;51(9):713-20. doi: 10.1016/j. archoralbio.2006.03.012.

4. Okeson JP. Tratamento das desordens temporomandibulares e oclusão. 6a ed. Rio de Janeiro:Elsevier; 2008.515p.

5. Teixeira MJ. Dor: manual para o clínico. São Paulo: Editora Atheneu; 2007.

6. Bodéré C, Téa SH, Giroux-Metges MA, Woda A. Activity of masticatory muscles in subjects with different orofacial pain conditions. Pain. 2005;116(1-2):33-41. doi: 10.1016/j. pain.2005.03.011.

7. Catanzariti JF, Debuse T, Duquesnoy B. Chronic neck pain and masticatory dysfunction. Joint Bone Spine. 2005;72(6):515-9. doi: 10.1016/j.jbspin.2004.10.007.

8. Cruccu G, Frisardi G, Pauletti G, Romaniello A, Manfredi M. Excitability of the central masticatory pathways in patients with painful temporomandibular disorders. Pain. 1997;73(3):447-54. doi: 10.1016/S0304-3959(97)00139-5.

9. Auerbach SM, Laskin DM, Frantsve LMA, Orr T. Depression, pain exposure to strressful life events, and long-term outcomes in temporomandibular disorders patients. J Oral Maxillo Surg. 2001;59(6):628-33. doi: 10.1053/joms.2001.23371.

10. Cauás M, Alves IF, Tenório K, Brasiliense Filho J, Guerra CMF. Incidências de hábitos parafuncionais e posturais em pacientes portadores de disfunção da articulação craniomandibular. Rev Cirur Traumatol Buco-Maxilo-Fac. 2004;4:121-9.

11. Celic R, Jerolimov V, Knezovic Zlataric D. Relationship of slightly limited mandibular movements to temporomandibular disorders. Bras Dent J. 2004;15(2): 151-4. doi: 10.1590/S010364402004000200012.

12. Miller VJ, Karic VV, Myers SL, Exner HV. Myogenous temporomandibulardisorderpatientsand thetemporomandibular opening index. J Oral Rehabil. 2000;27(8):720-2.

13. Taucci RA, Bianchini EMG. Verificação da interferência das disfunções temporomandibulares na articulação da fala: queixas e caracterização dos movimentos mandibulares. Rev Soc Bras Fonoaudiol. 2007;12:274-80.

14. Woda A, Foster K, Mishellany A, Peyron MA. Adaptation of healthy mastication to factors pertaining to the individual or to the food. Physiol Behav. 2006;89(1):28-35. doi: 10.1016/j. physbeh.2006.02.013.

15. Bianchini EMG, Paiva G, Andrade CRF. Movimentos mandibulares na fala: interferência das disfunções temporomandibulares segundo índices de dor. Pró-Fono R Atual Cient. 2001;19(1):718. doi: 10.1590/S0104-56872007000100002

16. Ferraz Júnior AML, Devito KL, Guimarães JP. Temporomandibular disorder in patients with juvenile idiopathic arthritis: clinical evaluation and correlation with the findings of cone beam computed tomography. Oral Surg Oral Med Oral Pathol Oral Radiol. 2012;114(3):51-7. doi: 10.1016/j.000o.2012.02.010. Epub 2012 Jul 6.

17. Murphy MK, MacBarb RF, Wong ME, Athanasiou KA. Temporomandibular disorders: a review of etiology, clinical management, and tissue engineering strategies. Int J Oral Maxillofac Implants. 2013;28(6):393-414. doi: 10.11607/jomi.te20. 